\title{
SISTEM INFORMASI KEGIATAN PEKERJAAN FISIK PROGRAM DMIJ BERBASIS WEB STUDI KASUS DESA SUNGAI PIYAI KEC. KUALA INDRAGIRI
}

\author{
Ahmad Suprianto ${ }^{1}$, Ilyas ${ }^{2}$, Samsudin ${ }^{3}$ \\ Program Studi Sistem Informasi, Fakultas Teknik, Universitas Islam Indragiri, Tembilahan \\ Email: asupriyanto@gmail.com (korespondensi)
}

\begin{abstract}
The problem that is often encountered in the reporting progress system is that village employees still often use consultant services to prepare DMIJ project reports, so they require additional costs for consulting services, not to mention the time required to complete so many DMIJ project reports. So that with the progress reporting information system and applications that will be designed, it can help the work process of village employees so that they no longer need consultant services in order to save budget costs and time. Then, the solution that expected for the web-based DMIJ physical work activity information system uses the Development Life System (SDLC) method, could help the employees in order to prepare the project report progress more quickly and precisely.
\end{abstract}

Keywords: Information System, Development Life System (SDLC), Desa Maju Inhil Jaya (DMIJ)

\begin{abstract}
Abstrak
Permasalahan yang sering ditemui pada system progress pelaporan bahwa pegawai Desa masih sering menggunakan jasa konsultan untuk pembuatan laporan proyek DMIJ, sehingga membutuhkan biaya tambahan pengeluaran untuk jasa konsultan, belum lagi waktu yang dibutuhkan untuk menyelesaikan laporan proyek DMIJ yang begitu lama, jadi dengan adanya system informasi progress pelaporan dan aplikasi yang akan dirancang dapat membantu proses pekerjaan pegawai Desa sehingga tidak lagi membutuhkan jasa konsultan demi penghematan anggaran biaya dan waktu. Maka solusi yang diharapkan pada sistem informasi kegiatan pekerjaan fisik DMIJ Berbasis Web menggunakan metode Sistem Develovment Life (SDLC) Studi Kasus Desa Sungai Piyai Kecamatan Kuala Indragiri dapat membantu para pegawai atau karyawan desa dalam proses pembuatan laporan kegiatan pekerjaan fisik sehingga laporan kegiatan pekerjaan fisik bisa dikerjakan dengan cepat dan tepat.
\end{abstract}

Kata kunci: Sistem Informasi, Sistem Develovment Life (SDLC), Desa Maju Inhil Jaya (DMIJ)

\section{PENDAhuluaN}

Desa adalah pemukiman manusia dengan populasi antara beberapa ratus hingga beberapa ribu jiwa dan berlokasi di daerah pedesaan. Secara administratif Indonesia, desa adalah pembagian wilayah administratif yang berada di bawah kecamatan dan dipimpin oleh Kepala Desa. Desa Maju Inhil Jaya (DMIJ) sebagai salah satu program pemerintahan dalam mengembangkan desa - desa se kabupaten Indragiri hilir, secara umum transportasi kedaerah - daerah dan desa banyak ditempuh melalui jalur transportasi sungai, laut yang relative mahal dengan beratnya kondisi serba minim.

\section{TINJAUAN PUSTAKA}

\subsection{Sistem}

Sistem adalah merupakan kumpulan elemen-elemen yang saling terkait dan bekerja sama untuk memproses masukan (input) yang di tujukan kepada sistem tersebut dan mengolah masukan tersebut sampai menghasilkan keluaran (output) yang diinginkan (Kristanto, 2008).

Sistem adalah suatu jaringan kerja dari prosedur-prosedur yang saling berhubungan, berkumpul bersama-sama 
untuk melakukan suatu kegiatan atau untuk menyelesaikan suatu sasaran yang tertentu (Jogiyanto, 2005).

Kata sistem merupakan istilah yang berasal dari bahasa yunani "sistem" yang artinya adalah himpunan bagian atau unsur yang saling berhubungan.Secara teratur untuk mencapai tujuan bersama.Sistem adalah kumpulan elemen-elemen yang saling terkait dan bekerjasama untuk memproses masukan yang ditujukan kepada sistem tersebut dan mengelola masukan tersebut sampai menghasilkan keluaran yang di inginkan

\subsubsection{Karakteristik Sistem}

1. Komponen sistem

Suatu sistem terdiri dari sejumlah komponen yang saling berinteraksi, yang artinya saling bekerja sama membentuk suatu kesatuan. Komponen-komponen sistem atau elemen-elemen sistem dapat berupa suatu subsistem atau bagianbagian dari sistem. Setiap subsistem mempunyai karakteristik dari sistem yang menjalankan fungsi tertentu dan mempengaruhi proses sistem secara keseluruhan.

2. Batasan sistem

Batasan sistem merupakan daerah yang membatasi antara suatu sistem dengan sistem yang lainya atau dengan lingkungan luarnya. Batas sistem ini memungkinkan suatu sistem dipandang sebagai satu kesatuan dan menunjukan ruang lingkup dari sistem tersebut.

3. Lingkungan luar sistem

Lingkungan luar dari suatu sistem adalah apapun diluar batas dari sistem yang mempengaruhi operasi sistem. Lingkungan luar sistem dapat bersifat menguntungkan dan dapat juga bersifat merugikan sistem tersebut. Lingkungan luar yang menguntungkan merupakan energi dari sistem dan dengan demikian harus tetap dijaga dan dipelihara. Sedangkan lingkungan luar yang merugikan harus ditahan dan dikendalikan, kalau tidak maka akan mengganggu kelangsungan hidup dari sistem.

4. 4. Penghubung sistem

Penghubung merupakan media penghubung antar satu subsistem dengan subsitem yang lainnya. Melalui penghubung ini memungkinkan sumbersumber daya mengalir dari satu subsistem ke subsistem yang lainnya. Keluaran dari satu subsistem akan menjadi masukan untuk subsistem yang lainnya dengan melalui penghubung. Dengan penghubung satu subsistem dapat berintegrasi dengan subsistem yang lainnya untuk membentuk satu kesatuan.

5. Masukan sistem

Masukan adalah energi yang dimasukkan ke dalam sistem. Masukan dapat berupa masukan perawatan dan masukan sinyal maintenance input adalah energi yang dimasukkan supaya sistem tersebut dapat beroperasi.

Signal input adalah energi yang diproses untuk didapatkan keluaran dari sistem.

6. Keluaran sistem

Keluaran adalah hasil dari energi yang diolah dan diklasifikasikan men-jadi keluaran yang berguna dan sisa pembuangan. Keluaran dapat berupa masukan untuk subsistem yang lain.

7. Pengolah sistem

Suatu sistem dapat mempunyai suatu bagian pengolah atau sistem itu sendiri sebagai pengolahnya. Pengolah yang akan mengubah masukan menjadi keluaran.

8. Sasaran sistem

Suatu sistem pasti mempunyai tujuan (goal) atau sasaran (objective). Kalau suatu sistem tidak mempunyai sasaran, maka operasi sistem tidak akan ada. Sasaran dari sistem sangat menentukan sekali masukan yang dibutuhkan sistem dan keluaran yang akan dihasilkan system(Jogiyanto,1997).

\subsection{2. klasifikasi sistem}

Sistem merupakan suatu bentuk integrasi antara satu komponen dengan komponen lainnya.Karena sistem memiliki sasaran yang berbeda untuk setiap kasus yang terjadi yang ada didalam sistem tersebut.

Oleh karena itu sistem dapat diklasifikasikan kedalam beberapa sudut pandang.Seperti contoh sistem yang bersifat abstrak, sistem alamiah sistem yang bersifat deterministic dan sistem yang bersifat terbuka dan tertutup. Adapun penjelasan lebih detail dan rinci akan dipaparkan dibawah ini:

1. Sistem diklasifikasikan sebagai sistem abstrak dan sistem fisik.Sistem abstrak adalah sistem yang berupa pemikiran atau ide-ide yang tidak tampak secara fisik. Misalnya sistem teologi, yaitu sistem yang berupa pemikiran-pemikiran 
hubungan antara manusia dengan tuhan.Sistem fisik merupakan sistem yang ada secara fisik, misalnya sistem komputer, sistem operasi, sistem penjualan, dan lain sebagainya.

2. Sistem diklasifikasikan sebagai sistem alamiah dan sistem buatan manusia. Sistem alamiah adalah sistem yang terjadi karena proses alam tidak dibuat oleh manusia (ditentukan dan tunduk kepada kehendak sang pencipta alam). Misalnya sistem perputaran bumi, sistem pergantian siang dan malam, sistem kehidupan umat manusia. Sistem buatan manusia adalah sistem yang dirancang oleh manusia. Sistem buatan manusia yang melibatkan interaksi manusia dengan mesin disebut denganhumanmachine system atau ada yang menyebut dengan man-machine system. Karena menyangkut penggunaan komputer yang berinteraksi dengan manusia.

3. Sistem diklasifikasikan sebagai sistem tertentu (deterministic system) dan sistem tak tentu(probabilistic system). Sistem tertentu beroperasi dengan tingkah laku yang sudah dapat diprediksi. Interaksi diantara bagian-bagianya dapat dideteksi dengan pasti, sehingga keluaran dari sistem dapat diramalkan. Sistem tertentu relatif stabil/konstan dalam jangka waktu yang lama. Sistem komputer adalah contoh dari sistem tertentu yang tingkah lakunya dapat dipastikan berdasarkan program yang dijalankan. Sehingga dapat dikatakan sistem yang deterministic adalah sistem yang tidak pernah mengenal dan menganut sistem demokrasi (suara terbanyak adalah suara tuhan), karena dalam sistem komputer misalnya seberapa banyak data yang salah yang dimasukan (menjadi input), maka hasilnya tetap akan salah, sebalikny satu saja yang benar dimasukan (menjadi input) diantara sekian juta data yang salah, maka hasil satu data tersebut akan menjadi benar.Sistem tak tentu adalah sistem yang kondisi masa depannya tidak dapat diprediksi karena mengandung unsur probabilitas. Sistem sosial, politik,dan sistem demokrasi merupakan sistem yang probabilistik/tak tentu, dalam sistem politik kondisi masa depannya tidak bisa diprediksi bahkan dalam beberapa waktu jam saja sudah berubah, kawan menjadi lawan dan lawan yang selalu dihujat berubah menjadi kawan dan didukung habishabisan.
4. Sistem diklasifikasikan sebagai sistem tertutup dan sistem terbuka. Sistem tertutup merupakan sistem yang tidak berhubungan dan tidak terpengaruh dengan lingkungan luarnya. Sistem ini bekerja secara otomatis tanpa adanya turut campur tangan dari pihak luarnya. Secara teoritis sistem tertutup ini ada, tetapi kenyataanya tidak ada sistem yang benar-benar tertutup, yang ada hanya realitively closed system(secara relatif tertutup, tidak benar-benar tertutup). Sistem terbuka adalah system yang berhubungan dan terpengaruh dengan lingkungan luarnya. Sistem ini menerima masukan dan menghasilkan keluaran untuk lingkungan luar atau subsistem yanga lain. karena sistem sifatnya terbuka dan terpengaruh lingkungan luarnya, maka suatu sistem harus mempunyai suatu pengendalian yang baik. Sistem yang baik harus dirancang sedemikian rupa, sehingga secara relatif tertutup karena sistem tertutup akan bekerja secara otomatis dan terbuka hanya untuk pengaruh yang baik saja (Jogiyanto, 1997).

\subsection{Konsep Dasar Informasi}

Istilah lain yang sering muncul dan sebagian orang menyebut informasi sebagai data yang telah diolah menjadi bentuk yang lebih berarti bagi penerimanya. Berikut beberapa pengertian informasi menurut para ahli antara lain sebagai berikut :

1. Gordon (1985) mendefinisikan informasi sebagai data yang telah di olah menjadi bentuk yang lebih berarti dan berguna bagi penerimanya untuk mengambil keputusan masa kini maupun yang akan datang.

2. Raymond McLeod(1995) mendefinisikan informasi sebagai data yang telah di olah menjadi bentuk yang lebih berarti bagi penerimanya. Di proses sedemikian rupa sehingga meningkatkan pengetahuan seseorang yang menggunakannya(Albahra, 2005).

3. Alter (1992) Mendefinisikan informasi sebagai kombinasi antara prosedur kerja, informasi, orang dan teknologi. Informasi yang di organisasikan untuk mencapai tujuan dalam sebuah organisasi.

4. Bodnar (1993) Mendefinisikan sebagai kumpulan perangkat keras dan perangkat lunak yang di rancang untuk mentransformasikan data kedalam bentuk informasi yang berguna (kadir, 2003). 
Dengan demikian informasi merupakan data yang telah diolah menjadi bentuk lain yang lebih berguna dan jelas manfaatnya serta memberikan suatu nilai yang lebih nyata. Informasi yang berkualiatas antara lain sebagai berikut :

1. Relevan

Informasi ini harus mempunyai manfaat bagi pengguna, sebab informasi ini akan digunakan untuk mengambil keputusan dalam memecahkan suatu masalah.

2. Akurat

Informasi yang dihasilkan harus bebas dari kesalahan-kesalahan dan tidak menyesatkan bagi orang yang menerima informasi tersebut.

3. Tepat waktu

Informasi yang diterima harus tepat waktu, sebab kalau informasi yang diterima terlambat maka informasi yang diterima sudah tidak berguna lagi.

4. Ekonomis, efisien dan dapat dipercaya

Informasi yang dihasilkan mempunyai manfaat yang lebih besar dibanding dengan biaya mendapatkannya dan sebagian besar informasi tidak dapat ditaksir keuntungannya dengan satuan nilai uang tetapi dapat ditaksir nilai efektipitasnya dan informasi yang dihasilkan dapat dipercaya dan tidak mengada-ada (Al-bahra, 2005).

\subsection{Konsep Dasar Sistem Informasi}

Sistem informasi merupakankumpulan dari perangkat keras dan perangkat lunak komputer serta perangkat manusia yang akan mengelola dan menggunakan perangkat keras dan perangkat lunak tersebut. Selain itu sistem informasi dapat didefinisikan sebagai berikut :

1. Sistem informasi yaitu sistem yang dibuat oleh manusia yang terdiri dari komponenkomponen dalam organisasi untuk mencapai suatu tujuan yaitu menyajikan informasi.

2. Sistem informasi yaitu sekumpulan prosedur organisasi yang pada saat dilaksanakan akan memberikan informasi untuk mengendalikan organisasi.

3. Sistem informasi yaitu suatu sistem didalam organisasi yang mempertemukan kebutuhan pengelola transaksi, mendukung operasi, bersifat material dan menyediakan pihak luar dengan laporanlaporan yang diperllukan (Kristanto, 2008).

\subsection{Metodologi pengembangan sistem}

Metodologi pengembangan sistem adalah suatu cara untuk mengembangkan atau merancang sebuah sistem, metode yang sering digunakan yaitu System Development Life Cycle (SDLC).

\subsection{Konsep Pemodelan Sistem}

Untuk mengembangkan sistem yang dianalisa, adapun alat bantu perancangan sistem yang digunakan berupa Bagan Alir Sistem, contex diagram Data Flow Diagram (DFD), Entity Relationship Diagram (ERD), dan Normalisasi.

\subsubsection{Diagram Konteks}

Diagram Konteks adalah diagram yang terdiri dari suatu proses dan menggambarkan ruang lingkup suatu sistem. Diagram konteks merupakan level tertinggi dari DFD yang menggambarkan seluruh input ke sistem atau output dari sistem. Ia akan memberi gambaran tentang keseluruhan sistem. Sistem dibatasi oleh boundary (dapat digambarkan dengan garis putus). Tidak boleh ada storedalam diagram konteks. (Al-Bahra,2005)

\subsubsection{DataFlow Diagram (DFD)}

DFD adalah suatu model logika data atau proses yang dibuat untuk menggambarkan dari mana asal data dan kemana tujuan data yang keluar dari sistem, dimana data disimpan, proses apa yang menghasilkan data tersebut dan interaksi antara data yang tersimpan dan proses yang dikenakan pada data tersebut.

\subsection{Database}

Basis data atau database adalah sekumpulan data yang memiliki hubungan secara logika dan diatur dengan susunan tertentu serta disimpan media penyimpanan komputer. (Mardianto, dkk, 2012)

\subsection{MySQL}

MySQL adalah sebuah program data base server yang mampu menerima dan mengirimkan datanya dengan sangat cepat, multiuser serta menggunakan perintah standar SQL(Structured Query Language)(Nugroho, 2005).

\section{Analisa dan Perancangan}

Pada analisa sistem ini akan di lakukan penguraian dalam satu sistem informasi yang utuh kedalam bagian-bagian komponennya dengan maksud untuk mengidentifikasikan dan mengevaluasi permasalahan-permasalahan sehingga di temukan kelemahannya. Sehingga dapat di 
usulkan perbaikan-perbaikan untuk mengatasi hambatan-hambatan dan memenuhi kebutuhan yang di harapkan. Analisa untuk sistem informasi penjualan dan pembelian motor bekas.

\subsection{Analisa Kelemahan Sistem}

Analisa kelemahan sistem bertujuan untuk menunjukkan masalah-masalah yang terjadi pada sistem lama. Berdasarkan hasil pengamatan peneliti pada Progres Pelaporan Kegiatan fisik Dana DMIJ yang terjadi dapat di jelaskan sebagai berikut :

1. Belum ada sistem yang dapat menangani masalah pelaporan kegiatan desa maju inhil jaya (DMIJ)

2. Pembuatan laporan kegiatan pekerjaan fisik yang masih menggunakan jasa orang lain bukan pegawai Desa sendiri, sehingga membutuhkan tambahan dana.

3. Tidak ada aplikasi yang dapat membantu pembuatan laporan kegiatan pekerjaan fisik desa maju inhil jaya (DMIJ).

\subsection{Analisa Kelemahan Sistem yang sedang berjalan}

Analisa kelemahan sistem bertujuan untuk menunjukkan masalah yang terjadi pada system yang lama. Untuk mengidentifikasi masalah yang ada maka dilakukan metode analisis pieces, yaitu analisa terhadap kinerja (performance), analisa informasi (information), analisa ekonomi (economy), analisa pengendalian (control), analisa efesiensi (efficiency) dan analisa layanan (service).

1. Analisa Kinerja (Performance analysis)

Analisis kinerja adalah kemampuan atau peningkatan terhadap kinerja (hasil kerja) sistem yang baru sehingga menjadi efektif. Kinerja yang diharapkan dapat mengatasi permasalahan yakni peningkatan efektifitas dan efisiensi dalam mengatasi masalah yang ada di pembuatan laporan mingguan yang masih menggunakan jasa konsultan sehingga membutuhkan tambahan dana yang besar.

2. Analisa informasi (Information analysis) Analisa terhadap informasi pembuatan laporan DMIJ dan informasi yang dihasilkan sangat lambat, sehingga tidak sesuai dengan kebutuhan dan menyulitkan bagi perangkat desa untuk mengetahui informasi tentang DMIJ yang mengakibatkan informasi yang dihasilkan tidak terpenuhi dengan baik .

3. Analisa Ekonomi (Economy analysis) Adanya pemborosan waktu dan alat-alat maka otomatis terjadi pembengkakan biaya yang masih belum efektif dan efisien dalam penggunaan biaya khususnya dalam biaya pembuatan laporan melalui konsultan sehingga membutuhkan biaya yang dianggarkan cukup besar.

4. Analisa Pengendalian (Control analysis) Pengendalian atau kontrol dalam sebuah sistem sangat diperlukan untuk menghindari dan mendeteksi secara dini terhadap penyalagunaan atau kesalahan sistem serta untuk menjamin keamanan data dan informasi. Dengan adanya kontrol maka tugas atau kinerja yang mengalami gangguan bisa diperbaiki.

5. Analisa Efisiensi (Eficiency analysis)

Efisien berhubungan dengan

bagaimana sumber daya yang akan di gunakan seminimal mungkin guna menghindari pemborosan. Atau menyangkut bagaimana caranya agar menghasilkan suatu output sebanyak banyaknya dengan iput sekecil mungkin.

6. Analisa Pelayanan (Service Analisis)

Pada sistem lama, pelayanan dari segi proses pemesanan dirasakan masih kurang efektif dan efesien.

\subsection{Analisa Kebutuhan sistem}

Analisa kebutuhan yang di perlukan adalah kebutuhan hardware dan software.

1. Kebutuhan hardware

Perangkat keras pendukung yang di gunakan dalam membangun dan pengembangan system ini adalah : CPU, Monitor, Keybord, Mouse dan printer.

2. Kebutuhan Software

Perangkat lunak pendukung yang di gunakan dalam membangun dan pengembangan system ini adalah sebagai berikut:

1) Sistem operasi windows 7 yang di gunakan untuk menjalankan program aplikasi.

2) Macromedia Dreamweaver 8 di gunakan untuk perancangan dan pembuatan aplikasi.

3) MySQL di gunakan untuk perancangan dan pembuatan database untuk system.

\subsection{Perancangan Sistem}

Pada perancangan sistem ini langkahlangkah yang dilkukan yaitu merancang proses dan merancang database terhadap system yang dirancang, kemudian merancang input dan output dari sistem tersebut. Dalam perancangan proses ada beberapa rancangan yang akan di paparkan, 
berikut ini adalah rancangan sistem secara umum .

\subsubsection{Diagram Konteks}

Adapun diagram konteks dalam perancangan sistem informasi Progres Pelaporan Kegiatan Pekerjaan Fisik Dana DMIJ adalah sebagai berikut:

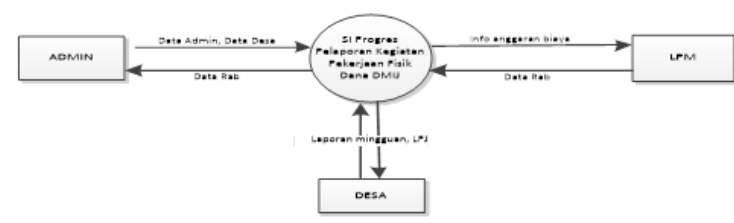

Gambar 1 Context Diagram

Pada gambar 1 diagram konteks admin memberikan masukan kepada sistem berupa data admin dan data desa, serta menerima masukan dari suatu sistem yaitu data Rab. Entitas Lpm memberikan masukan kepada sistem berupa data Rab serta menerima masukan dari sistem berupa info anggaran biaya, serta entitas desa menerima masukan dari sistem yaitu laporan mingguan dan LPJ.

\subsubsection{Data Flow Diagram Level 0}

Data Flow Diagram Level 0 berisi prosesproses yang menyusun sistem beserta aliran data tersebut. seperti gambar dibawah ini:

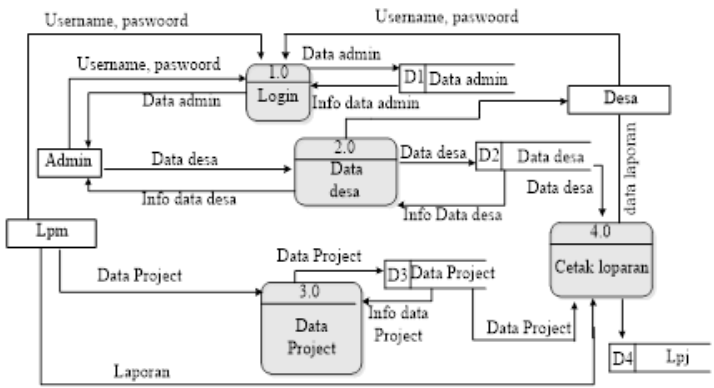

Gambar 2 DFD Level 0

Pada proses 1.0 merupakan login data admin, sebelum admin masuk kedalam sistem, admin terlebih dahulu melukukan login dengan mengimput user name dan pswoord. Setelah masuk kedalam sistem admin dapat melakukan proses 2.0 dimana admin bisa melakukan penginputan data desa, setelah data tersimpan. Ipm melakukan proses 3.0 data project dan bisa mencetak laporan. Setelah itu maka berlanjut proses 4.0 yaitu melakukan pencetakan laporan yang menggunakan data desa dan data rab

\subsection{Perancangan basis data}

Perancangan basis data ini ada beberapa yang perlu dilakukan yaitu menggambarkan ERD dalam mengetahui secara jelas hubungan system yang ada agar mempermudah dalam melakukan perancangan pada normalisasi.

\subsubsection{Entity Relationship Diagram}

Entity relationship diagram sebelum dirancang maka perlu dibuat hubungan antara entitas, relasi dan kardinalitas untuk melihat hubungan relasi itu dapat dilihat pada gambar sebagai berikut:

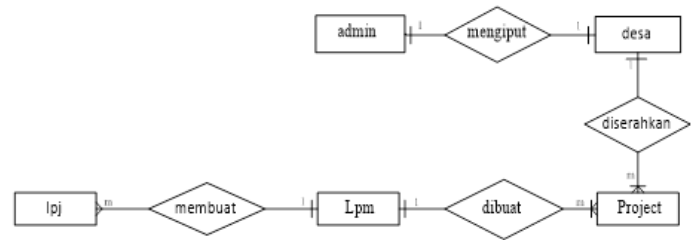

Gambar 3 Entity Relationship Diagram

Berdasarkan pada gambar diatas menggambarkan bagaimana relasi yang ada pada sistem progres pelaporan kegiatan pekerjaan fisik dana DMIJ. Pada entitas admin terhadap desa adalah one to one, karena satu admin hanya bisa mengiput satu desa, sedangkan pada relasi desa terhadap relasi project memiliki relasi one to one, karena satu desa diserahkan satu project, satu rab dibuat oleh satu Ipm dan satu Ipm membuat satu Ipj.

\section{Implementasi Sistem}

\subsection{Tampilan Form Login}

Dalam pengakasesan menu login, terdapat dua hak akses yaitu, hak akses admin dan user. Untuk hak akses admin yaitu meliputi hak akses yang mana seorang admin dapat merubah atau menghapus hak akses seorang user yang berupa sandi dan password, adapun tampilan menu login hak akses admin dan user pada gambar 4 dan 5 .

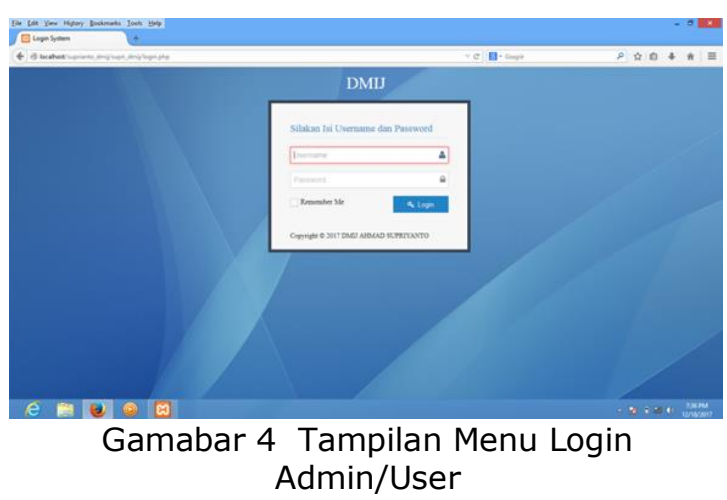

Pada gambar 4 adalah menu login untuk pengakses admin dan user, yang mana 
menu utama tidak akan tampil apabila seorang pengakses belum melakukan mengiputkan user dan password.

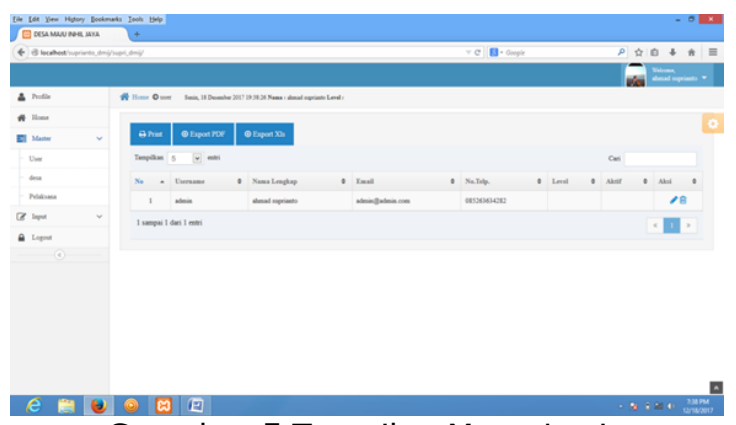

Gamabar 5 Tampilan Menu Login Admin/User

Pada gambar 5 merupakan gambar form untuk menentukan seorang hak akses, ada dua pilihan sebagai seorang pengakses yaitu admin dan user.

\subsection{Tampilan Form Menu Utama}

Tampilan menu utama merupakan tampilan masternya sistem ini, pada ini terdapat beberapa menu, seperti menu user, menu laporan, pasien, periksa dan keluar, dari menu tersebut memiliki beberapa sub menu pada gambar 6 .

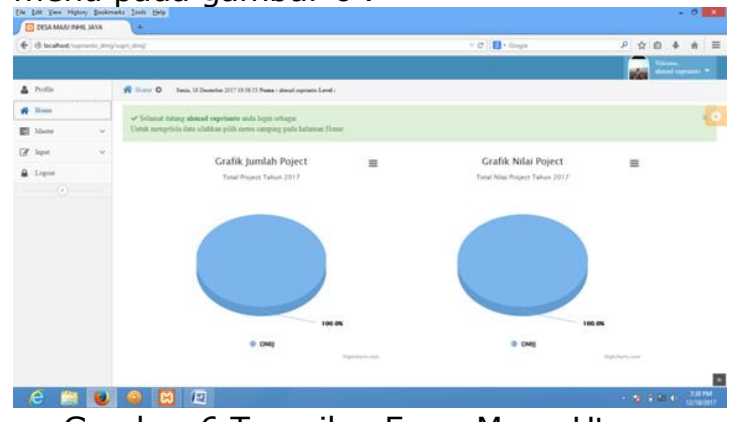

Gambar 6 Tampilan Form Menu Utama

\subsection{Tampilan Form Desa}

Tampilan Desa adalah tampilan untuk penginputan nama desa yang akan dilaksanakan pekerjaan, pada gambar 7.

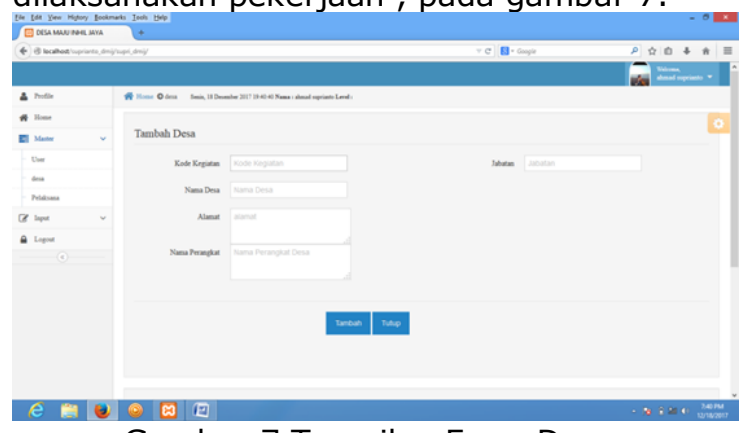

Gambar 7 Tampilan Form Desa
Pada gambar 7 merupakan form Desa untuk menginputkan nama desa yang akan di laksanakan pekerjaan dan harus sesuai dengan data didalam kontrak yang telah dibuat.

\subsection{Tampilan Laporan}

Tampilan Iaporan merupakan tampilan yang mana didalam laporan tersebut terdapat dua laporan yaitu laporan Pelaksana dan laporan Project, pada gambar 8 dan 9 .

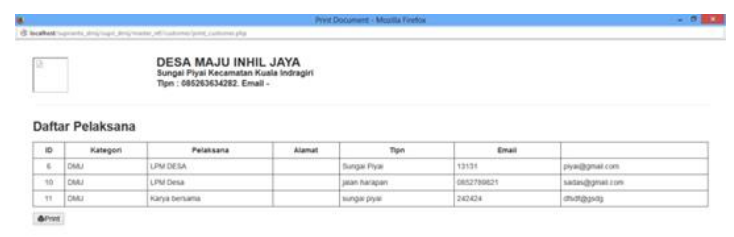

Gambar 8 Tampilan Laporan Daftar Pelaksana

Pada gambar 8 merupakan tampilan laporan Daftar Pelaksana yang akan dilaksanakan oleh beberapa pelaksana dan lokasi pelaksanaannya, laporan ini dapat disimpan berupa berkas maupun dalam bentuk file.

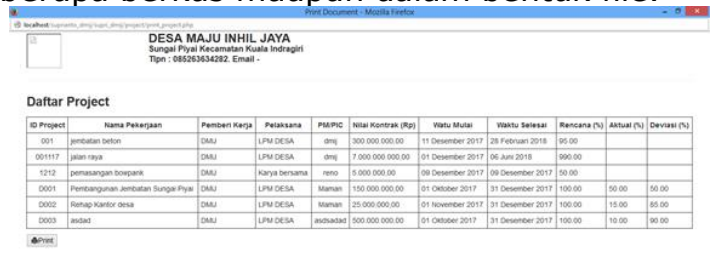

Gambar 9 Tampilan Laporan Daftar Project

Pada gambar 9 merupakan Daftar pekerjaan yang akan dilakukan oleh pelaksana kegiatandan di laporan ini terdapat nama pekerjaan dan waktu mulai .

\section{Kesimpulan dan Saran}

\subsection{Kesimpulan}

Dari hasil perancangan sistem informasi kegiatan pekerjaan fisik program DMIJ ini kesimpulan adalah :

1. Dengan adanya sistem informasi pekerjaan fisik DMIJ ini pengawasan pekerjaan fisik dapat dilakukan dengan mudah karena sistem ini menggunakan aplikasi berbasis WEB 
2. Dengan sistem informasi pekerjaan fisik program DMIJ ini mempermudah dalam pembuatan laporan progres kegiatan, sehingga tidak menggunakan jasa pihak lain.

3. Sistem ini dapat digunakan oleh admin dan dapat diakses oleh masyarakat agar dapat melakukan pengawasan bersama.

\subsection{Saran}

Berdasarkan hasil analisa yang telah dilakukan pada bab-bab sebelumnya, ada masukan yang dapat dikemukakan untuk pengembangan sistem informasi kegiatan pekerjaan fisik DMIJ dengan harapan semakin tepatnya antara kebutuhan sistem dengan fungsional perangkat lunak saransaran tersebut adalah :

1. Sistem informasi pekerjaan fisik DMIJ ini dapat disederhanakan tampilannya dan mudah digunakan, sistem ini dirasa banyak kekurangan dan kelemahan, sehingga adanya suatu pengembangan baru, agar sistem ini akan lebih baik lagi kedepannya.

2. Diharapkan kepada peneliti selanjutnya agar kebutuhan dapat tercapai dengan maksimal, serta menghasilkan informasi yang lebih baik dan sesuai dengan yang diharapkan.

3. Diharapkan adanya pemeliharaan pada sistem informasi ini agar sistem ini berjalan dengan baik.

\section{Daftar Pustaka}

[1] Al Bahra, B. L. (2005). Analisa Dan Desain Sistem Informasi. Yogyakarta: GRAHA ILMU

[2] Jogianto, H. M. (2005). Analisis dan Desain Sistem Informasi; Pendekatan Tersetruktur Teori dan Praktik Aplikasi Bisnis. Yogyakarta; Andi

[3] Jogianto, (1997). Sistem Informasi Berbasis Komputer . Yogyakarta:BPFE

[4] Kristanto, A. (2008). Perancangan Sistem Informasi dan Aplikasinya. Jakarta Gramedia Pustaka Utama.

[5] Kadir, A. (2003) Pengenalan Sistem Informasi. Yogyakarta: ANDI

[6] Kusrini dan Koniyo A.2007 Tuntunan Praktis Membangun Sistem Informasi Akutansi Dengan Visual Basic dan Microsoft SQL Server. Yogyakarta: Andi

[7] Nugroho, A (2005). Analis dan Perancangan Sistem Informasi Dengan Metodologi Berorientasi Objek. Bandung: Informatika 